\title{
Do the Slum Dwellers Enjoy the Basic Constitutional and Economic Rights as a Citizen in Bangladesh?
}

\section{Basharat Hossain}

Lecturer in Economics, Department of Business Administration, International Islamic University Chittagong, BANGLADESH

\begin{abstract}
Bangladesh is a country of about 156 million people including nearly 7.81 million of slum people. This paper investigates 28 years data for 1986- 2014 periods on the living standard of slum dwellers of Bangladesh. It presents the different forms of deprivations, sufferings and miseries of slum people from basic needs including social, constitutional and economic rights. More specifically, the wretchedness of slum dwellers in housing, drinking water, sanitation, food intake, healthcare, education, employment, income patterns, social status and security, economic and public assistance has been explored in this paper. In addition, poverty scenario and services of social organization among slum people has been focused in this paper. Finally, it recommends some policies to improve the living conditions of slum dwellers in Bangladesh.
\end{abstract}

Keywords: Slum Dwellers, Standard of Living, Basic Needs, Constitutional and Economic rights, Bangladesh

JEL Classification Code: I31, I38, I13, I18, I25, E26, O18, O15, O17

\section{INTRODUCTION}

Slum is a word, a name that reflects the distresses of deprived people who have to struggle with poverty to survive in this beautiful world. Slums and shanties are available in every country regardless developed or developing country. Usually, poor people migrated from village live in slumof urban areas. They choose the slum to livebecause they have no afforded. This paper is an effort to explore the social and economic sufferings of slum dwellers in Bangladesh and recommend some policy.

\section{Slum : Definition and Characteristics}

A slum can be defined as a cluster of housing units or a compact settlement with a minimum of 5-10 households or a mess unit with a minimum of 25 members and mostly very poor housing which grow unsystematically in government owned or private vacant land; very high population density and room crowding; very poor environmental services, 
especially water and sanitation; very low socio-economic status; lack of security of tenure (CUS, 2006). Basically, Slum houses are situated beside the main roads, highways, near the market places, railway stations, junctions, beside the railway line, or nearby mills, factories, small scale industries, etc. The physical and hygienic conditions of such houses are far below standard of urban residential area. Generally, this segment of people are distressed and forced to live in such unhygienic condition due to economic reason.

About 60 percent of the living condition of slums is characterized by high density living, inadequate of public goods, lack of basic facilities, unhealthy and contaminated environment, lacking of street lighting, insufficient or no paved streets, low literacy rate, unemployment, absent of ventilation in houses, lack of pure drinking water, underprovided electricity and sewerage facilities. Besides, some problems arise like unemployment, underemployment, crime, and creation of shanty towns, crime, social, moral and psychological abasement. Slums dwellers work mostly in informal sectors, characterized by low wage, insecurity and uncertainty of working hour. The major areas of working are garment industry, rickshaw pulling, street vending, construction works and petty business. (BBS, 1988, 1999, CUS, 2006, Hossain, 2011).

\section{Slum of Bangladesh: An Overview}

Bangladesh is the $5^{\text {th }}$ densely populated country in the world with 1.37 percent population growth per year (UN, 2012 and GOB, 2013). About 156 million people live in this country including 47 million poor and 7.8 million slum people. In addition, it is a 'Low human development county' and ranked 147 with Human development index (HDI) score 0.512 (UNDP, 2013, Hossain, 2014). However, Slum population increases in Bangladesh tremendously during $1986-2014$ periods. In 2014, the number of slum population stood at 7.8 million which is $839 \%$ higher than the number of 1986. IN 1990s, the counted slum dwellers are 2.57 million. Increasing trend is alarmingly high during 2000s. Basically, Slum population increases for eight reasons such as river erosion, uprooted, driven out, abandoned, insufficient income, insecurity, for job and others. Among the seven divisions of Bangladesh, the worse situation has seen in Dhaka, the capital city of Bangladesh, where about 4.28 million, (about $55 \%$ of total) people live in slum. The second highest proportion slum dwellers (20\%) live in Chittagong, the second largest city of Bangladesh followed by Sylhet (8.3\%), Rajshahi (7.1\%), Khulna $(5.7 \%)$. Only 3.9\%, the lowest percentage, live in Barisal division [See Fig 1 and 2].

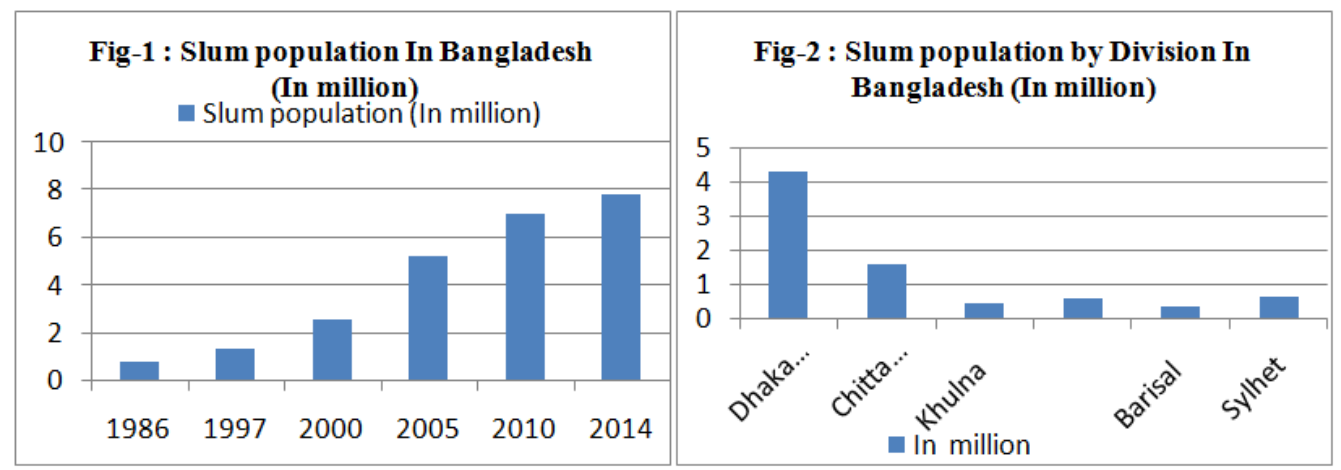

\section{Basic Constitutional and Economic Rights of the Citizen in Bangladesh}

The 15th section of Bangladesh constitution reveals the 'provision of basic necessities of life'. It states that, it shall be a fundamental responsibility of the State to ensure the 
'necessities of life,' including food, clothing, shelter, education and medical care; the right to work and guaranteed employment at an equitable wage; the right to reasonable rest, recreation and leisure; and the right to social security, public assistance in cases of undeserved want arising from unemployment, illness or disablement, or suffered by widows or orphans or in old age, or in other such cases. Free and compulsory education and public health are also the basic rights of a citizen as described by the 17th and 18thsection of Bangladesh constitution. These are the fundamental rights of a citizen in the country to attain a constant increase of productive forces and a steady improvement in the material and cultural standard of living of the people (GOB, 1972).

\section{OBJECTIVE}

The prime objective of this paper is to reveal the miseries of the slum dwellers in living conditions of Bangladesh. More specifically, the aim of this study is to explore the different forms of their deprivations, sufferings and miseries from basic needs including social, constitutional and economic rights.

\section{Methodology}

This paper is a descriptive analysis on miseries of slum people in Bangladesh. It has been prepared by using secondary data. The data on slums are mainly collected from the slum area census 1986, the Census of slum areas and Floating Population 1997, Slum of urban Bangladesh, Mapping and Census, 2005 and multiple Indicator Cluster Survey 2006-2009. The information of Bangladesh economy is gathered from Bangladesh Bureau of Statistics, Bangladesh Economic Review 2013-2014, United Nations, etc. Moreover, relevant research papers, books, newspapers, websites, periodicals are reviewed in preparing this article.

\section{LITERATURE REVIEW}

Different research works have been conducted on health service, livelihood, and education and NGO coverage among the slum dwellers of Bangladesh. Alamgiret al. (2009) examines the factors affecting the livelihood of migrants' slum dwellers in Dhaka city. Water Supply and Sanitation facilities in Rajshahi Slums areas are explored in the paper of Alam et al. (2013). Hossain (2011) in his book describes the urban slum poverty in Bangladesh. Sharifa and Sen (2004) show the unsustainable livelihood of urban slum poor. Hanchett et al. (2003) discuss the environmental problem of slum areas in Bangladesh. Cameron (2009, 2010) explains the educational status and amenities for urban slum people. Some health and educational indicators of Bangladeshi slum dwellers has been described in a report of UNICEF (UNICEF, 2010). Hossain (2011) give an overview on the slum areas of Bangladesh. Turin et al. (2007) shows the dietary pattern and food intake habit of urban slum children. Changing Patterns in Lifestyle of urban slum people has been disclosed in the article of Islam et al. (2012).

However, this research paper is different from the earlier research in a sense that, it scrutinizes 28 year's data for 1986- 2014 periods, which is longer duration than previous studies. In addition, this paper investigates the living standard of slum dwellers in a whole country and exposes all forms of deprivations and miseries including social, constitutional and economic forms. 


\section{Basic Constitutional and Economic Rights of the Citizen and the CONDITION OF SLUM DWELLERS IN BANGLADESH}

\section{Shelter and Housing Structure of Slum Dwellers'}

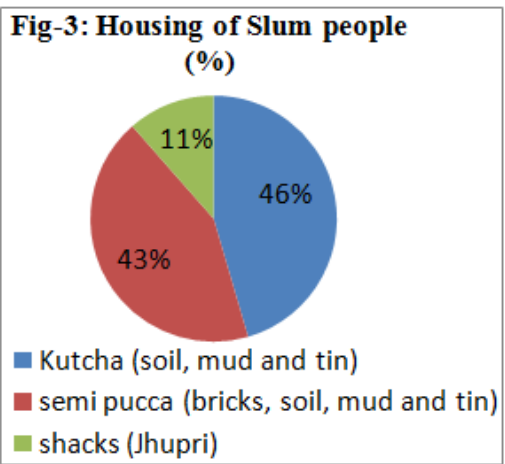

The slum peoples have shelter but their housing structure is fragile and population density in slum areas is scarily high. The average population density in slums is 831 persons per acre that is seven times higher than that of national average. Furthermore, the melancholies of slum dwellers are begun from their living places. Flooding, inadequate space, unhealthy environment is the common characteristics of slum houses. Most common form of the slum houses are Shacks (Jhupri), Bamboo structured house, Tin shed, Chhai (made of fodder), semi Pucca (made of bricks, soil, mud and tin), Kutcha fragile structure (made of soil, mud and tin), Derelict old buildings. In Bangladesh, 44.8 percent slum households are living in Kutcha housing followed by semi pucca 42.4 percent and 11.3 percent in shacks (Jhupri) respectively (BBS, 1988, 1999,CUS, 2006, UNICEF, 2010) [See Fig 3].

\section{Living Environment and Waste Disposal}

According to International Organization for Migration (IOM), about 70\% of slum dwellers in Dhaka face different environmental shocks and difficulties (IOM, 2007). The living environment of the slums is dangerous for health mainly because of having no fixed place for waste disposal and unhygienic conditions with inadequate services and facilities (Parvin and Shaw, 2011). A study of Unnayan Onneshan finds that, 57 percent of households dispose of wastes into the water body while 42 percent of households dispose of on the ground, mainly on the street. Though, only 1 percent of households have been found to dispose wastes in dustbin (Akter, 2010).

Rights of Property and Ownership

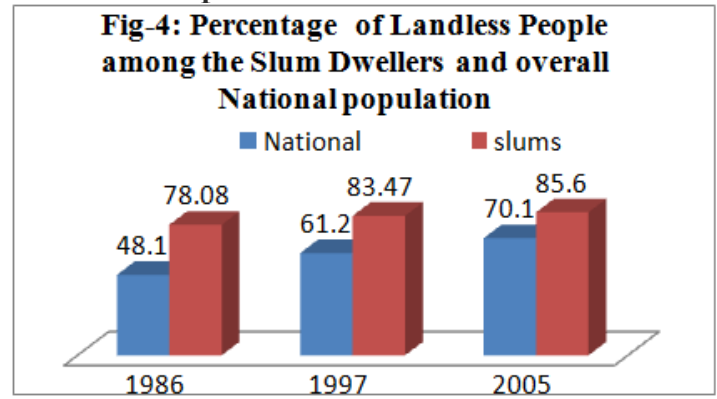


In Bangladesh, about 70 percent people are completely landless and this number is rising tremendously (Uddin, 2002, BBS, 2008). This scenario among the slum people is more stressful and recorded as $20 \%$ higher than the national average. In 1986, about 78.08 percent slum people were landless which rises to d 85.6 percent in 2005 . About $73.9 \%$ of slum households live in rented land (BBS, 1999, CUS, 2006) [See Fig 4].

\section{Food Items and Expenditure of Slum People}

Food insecurity and low dietary diversity is a common phenomenon for slum dwellers in Bangladesh. It is found in the research that, about 65 percent of total income of slum households is spent on food items. Nevertheless, 96.02 percent households rarely had more than two meals in a day (Akter, 2010). Moreover, About 26 percent of the total slum population consumes less than 80 percent of its recommended daily calorie consumption (IFPRI, 2007). The usual items of meal include rice, potato, flour, vegetable, edible oil and fish (weekly) and all of these are in form of lowest quality and cheapest price. On the contrary, nutritious and protein rich product (meat, egg, milk, milk product, fruits (only banana)) are rarely consumed monthly, bi-monthly or during occasions and festivals. But most of them are categorized by lowest quality in taste. Besides, slum dwellers eat unsafe street food for its ease and affordability, which may cause renal failure, cancer and liver damage and all fatal diseases.

\section{Sources of Drinking Water}

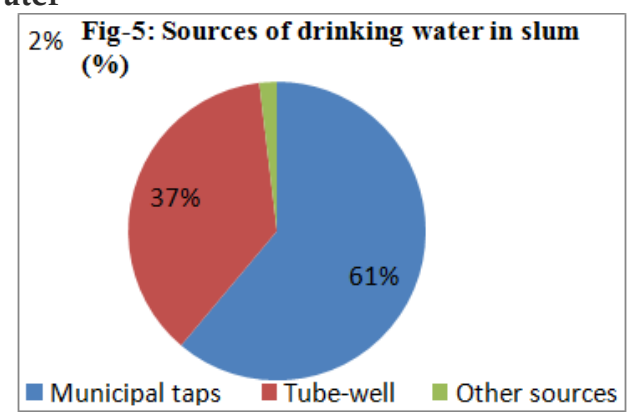

Slum censuses reported that, about $61.10 \%$ slum households are getting their drinking water from the municipal taps followed by $37 \%$ from tube-well and $1.90 \%$ from other sources respectively [See Fig 5]. Furthermore, 88 percent of them drink the unsafe and germ-infested water without boiling or filtering, Lack of affordability in buying gas or fuel, lack of knowledge is the main causes behind the drinking unsafe water. Moreover, the have to spend about $37 \%$ of their daily time. About 50 percent of total slum children are found sick due to different types of water-borne diseases. Among them, 67 percent of affected children have been reported as suffering from diarrhea and cholera respectively (Turin et al. 2007, Alam et al. 2013).

\section{Health Care}

High density of population, filthy environment, polluted water, and poor sanitation worsen the risks of waterborne and airborne diseases, such as cholera, diarrhea, pneumonia, influenza and tuberculosis. Most of the times in the year, about 31.36 - $44.67 \%$ slum people suffer from different diseases, 72 and 48 percent of them are female and male respectively. Only $2.4 \%$ of them get treatment from government and NGO hospitals for healthcare while $93 \%$ of slums do not have Public health care clinics in Bangladesh. In addition, though the mortality rate (75 
per 1,000 live births) among the slum children(under five) is decreasing but still nearly $12 \%$ higher than the overall urban rate (53 per 1,000 live births) and 9.5 percent higher than the rural rate. Besides, 60 percent of slum children are underweight and malnourished because of low initial breastfeeding rate (35\%) (Turin et al. 2007, UNICEF, 2010).

\section{Literacy among Slum People}

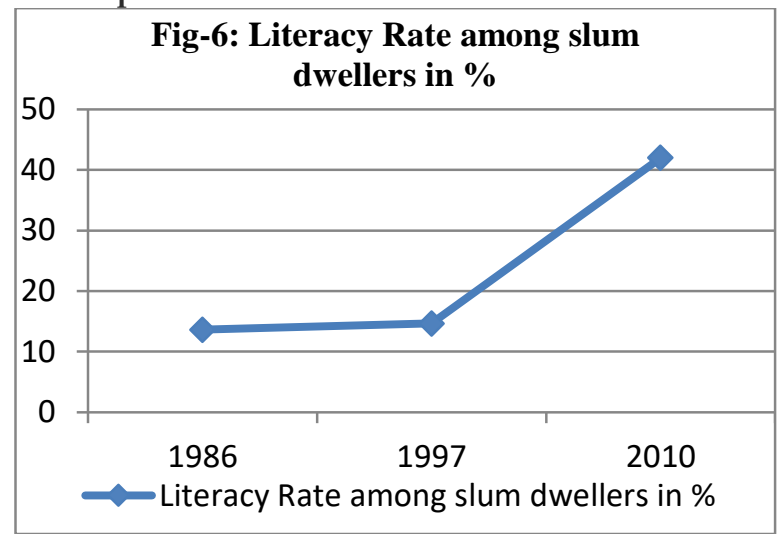

Literacy refers to the ability to write a letter. The literacy rate among the slum people increased significantly during 1986-2010 periods. In 2010, about 42 percent slum people (age 7+) were literate that is at least three times higher than the literacy rate of slum people in 1986. Moreover, the percentage of literacy rate is higher among male (18.19 percent) than the female (9 percent) population in the slum areas. Youth literacy (women aged 15-24 years) is 51\% and adult literacy (women aged 15-49 years) is 35\% only, net attendance ratio in pre-school education is $13 \%$, net attendance ratio in primary education is $65 \%$, drop out in primary education is $8 \%$ which is $700 \%$ higher than the rural rate, net attendance ratio in secondary education is $18 \%$ which $63 \%$ lower than the corresponding rural rate [See Fig 6]. The literacy rate of slum people is very low because of inadequate number of school, no opportunity of education for worker slum people (BBS, 1986, 1997, Cameron, 2009, 2010, UNICEF, 2010, CEDAR Barefoot Walk \& SATHI, 2011). Baker (2007) in his study finds that there is at least one government school is available in 26 percent of slums in Dhaka city and 27 percent of slum have an NGO operated school but 47 percent slum have no school for education. But in other divisions, such numbers of schools are not available for slum dwellers.

\section{Employment Scenario}

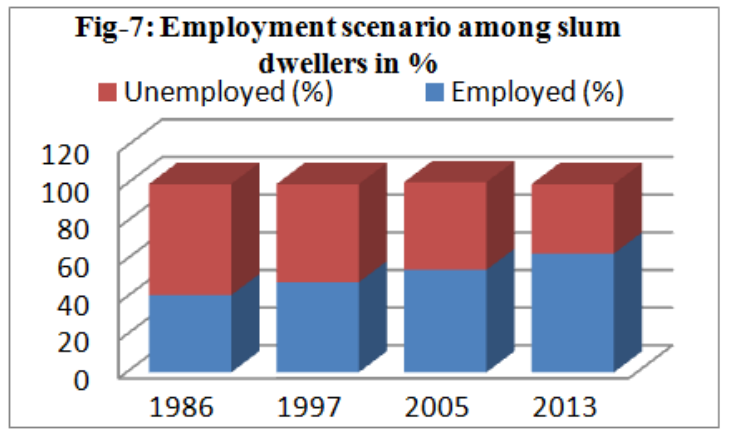


A person is employed who is engaged in some gainful work. Most of the slum dwellers including children and women are involved in some activities in exchange of some benefits either in cash or kind. About $63.12 \%$ of the slum populations are working where $65.53 \%$ are male, and $34.47 \%$ female respectively [See Fig 7]. On the other hand, 36.88\% people including children and student are unemployed due to having no specific job. Slums have three times more child labour than the national average. Basically, Slum peoples are involved in the low wage informal sectors. The different forms of activities in informal sector are Rickshaw pulling, sewing, hawking, working in garments, street vending, garbage Collecting, knife sharpening, construction worker, drug peddling, driving, snake charming, Cleaning, sweeper, mechanics, carpenters, small artisans, transport worker barbers, shop keeping, and maid servant. It is reported that, only $5.5 \%$ slum people get low wage job in the formal sector. Slum people have to bribe influential local persons including chairman Upazila, Ward Commissioners, government employee, local political party leaders, to provide the guarantor, to get job in the formal sector such as garment, worker in government and private organization (Rashid, 2004, CUS, 2006, UNICEF, 2010).

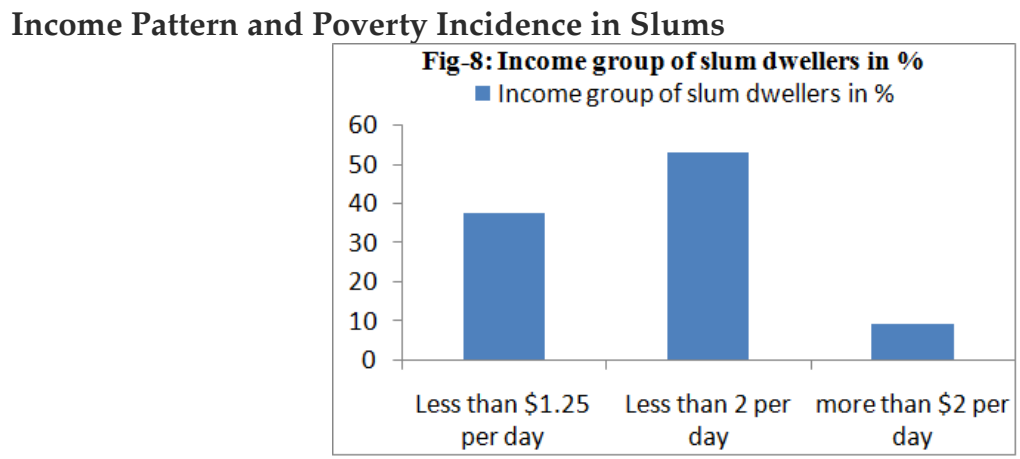

UN-HABITAT reported that, about 85 percent of urban slum dwellers are poor in Bangladesh (UNHABITAT, 2005). Recent data of Bangladesh Bureau of Statistics reveals that, 47.8 Percent of slum dwellers are absolute poor, who intake less than 2,122 kilo-calorie food per person per day and 29 Percent are found as hardcore poor, who intake less than 2,122 kilo-calorie food per person per day(BBS, 2005, 2010). The slum census report-2005 revealed that, 37.5 percent slum people are extreme poor who earn less than $\$ 1.25$ per day and 53.3 percent are moderate poor whose per day income is less than $\$ 2$. Only 9.1 percent have more than $\$ 2$ income per day [See Fig 8]. In addition, the overall poverty incident is very high among the slum dwellers in almost all division (seven divisions) of Bangladesh. The 99.9 percent of slum people are poor in Barisal division, among of them 44.8 percent are extremely poor. Khulna division has 99.7 percent slum poor whereas 99.5 percent, 97.1 and 94.1 slum poor live in Rajshahi, Chittagong and Sylhet divisions respectively. Dhaka, the capital city of Bangladesh, is slightly in the better position, with 14.6 percent slum dwellers have income $\$ 2$ per day and slum poverty rate is 85.4 percent. The highest, 54.3 percent extreme slum poor are living in Khulna division followed by Rajshahi (52.1 percent), Barisal (44.8 percent), Chittagong (36.8 percent) and Dhaka (19.6 percent) respectively. The lowest, 1.9 percent extreme slum poor live in Sylhet division (CUS, 2006, UNICEF, 2010).

\section{Sources of Light and Fuel}

Electricity is the source of light for $91.1 \%$ slum households, $8 \%$ use Kerosene for lighting and 0.9 $\%$ has no arrangement for lighting. Moreover, the slum dwellers usually use dry straw, cowdung, dry leaves, husk, wood, gas, etc. as fuel for preparation of their meals. Besides, only $44.6 \%$ of slum households have access to gas for cooking. But it is not available for the slum in Khulna, Rajshahi and Barisal divisions (BBS, 1999, UNICEF, 2010). 


\section{Toilet and Sanitation Facility}

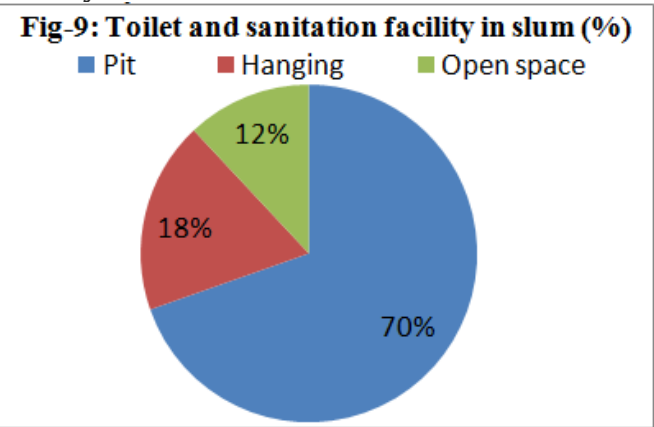

The alarming scene is that, about 80 percent of the slum population in Bangladesh has no sanitation facilities. The slum censuses reported that, unsafe, unhealthy and open space toilets are available in the slum. Furthermore, $92 \%$ slum people share their latrines and use some common form of toilets such as pit $(52.2 \%)$ followed by hanging $(13.8 \%)$ and open space $(8.99 \%)$ [See Fig 9]. Only 9\% slum people use improved sanitation which is 83 $\%$ lower than the overall rural rate (54\%), (UNICEF, 2010). Islam et al. (2012) stated that, only 14 percent of the slum households have sanitation facilities in Dhaka city.

\section{Social Security and Problems}

Most of the slum houses (86\%) have no tenure security. At any times and any days, it might be evicted. Consequently, worry and depression become the permanent distress of slum dwellers in Bangladesh. Besides, 17.21\% have a disabled or economically-inactive member in their family (DSK, 2011). Moreover, the housewives and girls are often abused, teased and extorted by the local Terrorist (Mastaans). In addition, slum dwellers are forcibly or in greed of money involved in violence (Islam et al. 2009), Anam, 1993). Sometimes, they have to bribe influential local political party leaders and terrors. Though they get help from some NGOs, law enforces agencies are not helpful for them. However, due to very low socioeconomic status (96.9\%) of slum people, they sometimes are engaged in unsocial and immoral activities. Such as crimes, snatching, stealing, drug selling and addiction, smuggling, prostitution, mugging, child trafficking (Islam, 2012).

\section{Social and Economic Assistance}

About $71.5 \%$ of the slums areas are under the coverage of different NGOs, social, Government, savings or credit and non-profit organization. Different organizations including (typically known only by their acronyms) Water aid, WASA, BRAC, DSK, icddr'b, Muslim aid, ASA, BURO, BRAC, JCF, PMUK, SAJIDA, SSS, TMSS, PROSHIKA, SHAKTI, SEEP, and Padakkhep are generally provide health care, education, microcredit, water supply, family planning services (DSK website 2012). Moreover, about 13.1\% and 58.4\% slum households receive services from one and more than one organization respectively. Among the six division of Bangladesh, Rajshahi received the highest services followed by Barisal, Dhaka, Khulna, Chittagong and Sylhet respectively. As a result, the economic, social and decision-making status of slum people improved substantially (Alamgiret al. 2009).

\section{SUMMARY OF FINDINGS}

About, 7.81million people live in slum areas that are $15 \%$ of the total population in Bangladesh. About 85 percent slum people are completely landless. Most common form of the slum house is Shacks and the average population density in slums is 831 persons per 
acre. Thecommon physical condition of slums is unhygienic and polluted where fundamental constitutional and economic facilities are absent. Moreover, 96.02 percent households rarely had more than two meals in a day, 88 percent of them drink the unsafe and germ-infested water, 50 percent of total slum children are found sick, about 31.36 $44.67 \%$ slum people suffer from different diseases in most of time in a year, $93 \%$ of slums do not have Public health care clinics, youth literacy (women aged 15-24 years) is 51\% and adult literacy (women aged 15-49 years) is 35\% only, About $63.12 \%$ of the slum populations are employed in the low waged informal sectors, 47.8 Percent and 29 Percent of slum dwellers are absolute and hardcore poor, Electricity is the source of light for 91.1 $\%$ slum households. Only 9\% slum people use improved sanitation; 86\%slum houses have no tenure security; the socioeconomic status of slum people is very low, and they sometimes are engaged in crimes. About $71.5 \%$ of the slums areas are under the coverage of different NGOs, social, Government, savings or credit and non-profit organization and working to improve the living condition of slum people.

\section{RECOMMENDATIONS}

Since, donation or charity is not a permanent solution. So, well-designed development program or project should be taken slum people by the government and Development NGOs in the forms that make them self-dependent to improve their standard of living. If the slum people become educated, they will earn their livelihoods pleasantly. Moreover, Special program for rehabilitations are needed because 70 percent of slum dwellers are landless. Besides, free-education programs for children, old aged people, training programs for men and women, awareness raising program, transfer payments for disabled or ill people, offering part-time jobs, interest free loan or loan at lowest rate of interest, religious motivation to reduce crimes, Special subsidy or donation for pure drinking Water and sanitation, program for poverty alleviation, arranging special branch of law enforcing agencies, organizing several market for informal sector or any other possible ways should be taken by the government and other social organization. In addition, Government may impose the poll tax on the richest man or collect the Zakah (obligatory Islamic tax) money (2.5\%) from them in the country.

\section{CONCLUSION}

"Slum life" is another form of the nightmare, life of human as non-human being, and the final deprivation from fundamentals constitutional and economic rights. It is proved from the description of this paper. Though every government committed to eradicate poverty completely, they did not yet take the appropriate program to save the lives of 7.8 million slum people, it is urgent to take immense steps by government, NGOs, even an individual. Otherwise, instead of becoming a peaceful and developed nation, our country will be a hell for us.

\section{References}

Akter, Tahera, (2010), Migration and living conditions in urban slums: implications for food security, published by Unnayan Onneshan, Dhaka, Bangladesh Web: www.unnayan.org, http://www.unnayan.org/reports/Migration.and.living.conditions.in.urban.slums.pdf

Alam, Md. Zahanggir; Rahman, Md. Alinur; Firoz, Md. Abdullah Al (2013), Water Supply and Sanitation Facilities in Urban Slums: A Case Study of Rajshahi City Corporation Slums, American Journal of Civil Engineering and Architecture, Vol. 1, No. 1, 1-6

Alamgir, M. S., M. A. Jabbar and M. S. Islam (2009),Assessing the Livelihood of Slum Dwellers' in Dhaka city, Journal of. Bangladesh Agricultural University. Volume 7, Issue 2, pp.: 373-380, 
Anam, Shaheen (1993), staying alive: urban poor in Bangladesh, UNICEF, pp. 13

Baker, J.L. (2007), Dhaka: improving living conditions for the urban poor. World Bank

BBS (1988), Report on the slum area census 1986, Bangladesh Bureau of Statistics, pp. 4, Dhaka, Bangladesh,

BBS (1999), Census of slum areas and Floating Population 1997, Volume-1, Bangladesh Bureau of Statistics, pp. 2, Dhaka, Bangladesh

BBS (2005, 2010), Household Income and Expenditure Survey (HIES) 2005 and 2010, Bangladesh Bureau of Statistics, Dhaka, Bangladesh

BBS (2011), Bangladesh Population and Housing Census 2011, Bangladesh Bureau of Statistics, Dhaka, Bangladesh, retrieved from:http://www.bbs.gov.bd/Home.aspx\#

Cameron, Stuart (2009), Education in slums of Dhaka, Bangladesh, Paper prepared for the $10^{\text {th }}$ UKFIET International Conference on Education and Development, 2009

Cameron, Stuart (2010), Access to and Exclusion from Primary Education in Slums of Dhaka, Bangladesh

CEDAR Barefoot Walk\&SATHI, (2011), Hope for Urban Slum Dwellers in Bangladesh, CEDAR Barefoot Walk\&SATHI. Retrieved from: http://cedarbarefootwalk.wordpress.com/2011/09/30/hopefor-urban-slum-dwellers-in-bangladesh/

CUS (2006), Slum of urban Bangladesh, Mapping and Census, 2005, Centre for Urban Studies (CUS), Dhaka, Bangladesh

DSK Website (2012), Working Area, Dushtha Shasthya Kendra, DSK, Website: www.dskbangladesh.org, (Accessed on 24.12.2012)

GOB (2013), Bangladesh Economic Review 2013, Ministry of Finance, Government of Bangladesh, Dhaka, retrieved from: http://mof.gov.bd/en/index.php?option=com_content\&view=article\&id=72\&Itemid=1

GOB, (1972), The Constitution of the People's Republic of Bangladesh, PART II, fundamental principles of state policy, PART III, fundamental Rights. Government of Bangladesh, accessed from http://unpan1.un.org/intradoc/groups/public/documents/APCITY/UNPAN014593.pdf

Hanchett, Suzanne; Akhter, Shireen; Khan, Mohidul Hoque; Mezulianik, Stephen and Vicky, Blagbrough (2003), Water, sanitation and hygiene in Bangladeshi slums: an evaluation of the Water Aid- Bangladesh urban programme, International Institute for Environment and Development, Published by: http:/ / www.sagepublications.com

Hora EA. 2014. Factors that affect Women Participation in Leadership and Decision Making Position Asian Journal of Humanity, Art and Literature, 1, 97-117.

Hossain, Basharat (2011), Slum of Bangladesh: An Overview, retrieved from: http:/ /economicsbd.wordpress.com/2011/03/06/a-brief-history-of-economics /

Hossain, Basharat (2014); Poverty Reduction during 1971-2013 Periods: Success and its Recent Trends in Bangladesh, Global Journal of Human-Social Science: E-Economics, Volume 14 Issue 5 (Ver. 1.0).pp.39-47

Hossain, Shahadat (2011), Urban Poverty in Bangladesh: Slum Communities, Migration and Social Integration, I.B.Tauris \& Co Ltd, London

Hussain DB, Chaudhry DW and Askar A. 2012. From Providing 'Alternative Punishment' to Offering 'Punishment in the Community': The History and Development of Community Penalties in Britain ABC Journal of Advanced Research, 1, 15-22.

IFPRI (2007), Study of Household Food Security in Urban Slum Areas of Bangladesh, 2006,published by International Food Policy Research Institute, Final Report for World Food ProgramBangladesh, Washington, D.C.USA

IOM (2007), Discussion Note: Migration and the Environment. MC/INF/2008, International Organization for Migration 
IOM- Mahajan, D. (2010). No Land's Man: Migration in a Changing Climate. In, On the Move: Migration Challenges in the Indian Ocean Littoral, E. Laipson and A. Pandya (Eds.), The Henry L. Stimson Center, Washington DC

Islam, Atikul (2012), Crimes at the Urban Slum: A sociological study on the crimes committed at Mohammadpur Geneva Camp, Dhaka, Bangladesh, pp.9-25, LAP LAMBERT Academic Publishing

Islam, M S; Kurshed, AAM; Azad, TMAand Bhuyan, M A H;(2012), Changing Patterns in Lifestyle, Food Intake and Health Status between Selected Beneficiary People and Non-beneficiary People of Urban Slum in Dhaka City, Bangladesh Journal of Nutrition, Vol. 24-25, Institute of Nutrition and Food Science, University of Dhaka, Dhaka-1000, Bangladesh.

Islam, Nazrul;Mahbub, Dr. AQM and Nazem, Dr. Nurul Islam(2009); urban slums of Bangladesh, the Daily star, Published On: 2009-06-20. Retrieved from: http:/ / www.thedailystar.net/story.php?nid=93293

Lashari NA and Mohyuddin DA. 2012. Economic Activities among Barra Community in Sindh, Pakistan: A Case study of Matli Town, District Badin ABC Journal of Advanced Research, 1, 23-31.

Mitiku W, Alemu Y and Mengsitu S. 2014. Challenges and Opportunities to Implement Inclusive Education Asian Journal of Humanity, Art and Literature, 1, 118-135.

Parvin, G. A. and Shaw, R. (2011), Climate Disaster Resilience of Dhaka City Corporation:An Empirical Assessment at Zone Level, Risk, Hazards \& Crisis in Public Policy, 2(2),Art.6

Rahman MS and Islam MS. 2012. An Analytical Study on Determining Effective Factors for Recruiting Right Person ABC Journal of Advanced Research, 1, 50-56.

Rashid, Sabina Faiz (2004), worried lives: poverty, gender and reproductive health of married adolescent women living in an urban slum in Bangladesh. Doctoral, Australian National University, July

Roshan KM. 2014. Contextualizing Power Politics of Tamasha Art and Female Suffering in Dalit Autobiography Asian Journal of Humanity, Art and Literature, 1, 77-83.

Sharifa, Begum and Sen, Binayak (2004), Unsustainable Livelihoods, Health Shocks and Urban Chronic Poverty Rickshaw Pullers as a Case Study, Mimio, Chronic Poverty Research Centre and Bangladesh Institute of Development Studies, Dhaka, Bangladesh

Turin, Tanvir Chowdhury; Rumana, Nahid; Shahana, Nahid (2007), Dietary Pattern and Food Intake Habit of the Underprivileged Children Residing in the Urban Slums, Iran J Pediatr, Vol 17 ,No 3;227-234

Uddin,Muhammed Kamal (2002), needs for land and agrarian reform in Bangladesh, Paper presented in the Regional Workshop on Land Issues for Asia held on 4-6, June 2002, in Phnom Penh, Cambodia

UN-HABITAT (2005), Slum trends in Asia,UN-HABITAT Global Urban Observatory 2005, pp.2-3

UNICEF, (2010),Understanding Urban Inequalities in Bangladesh: A prerequisite for achieving Vision 2021, a study based on the results of the 2009 Multiple Indicator Cluster Survey, United Nations Children's Fund (UNICEF), Bangladesh.

United Nation (2012), World Population Prospects: 2012 revision, Department of Economic and Social Affairs Population Division, United Nations 
Publish online and print version both 